\title{
Gender and Piece Rates, Commissions, and Bonuses
}

\author{
LORI A. GEDDES and JOHN S. HEYWOOD*
}

\begin{abstract}
Previous work shows that establishments with higher proportions of women are more likely to use piece rates but that individual women are less likely to receive performance pay. We present a model in which lower expected tenure and labor force attachment are positively associated with piece rates but are negatively associated with other forms of performance pay. Analysis of the National Longitudinal Survey of Youth (NLSY) confirms that women are more likely to be paid piece rates and simultaneously less likely to be paid commissions and bonuses.
\end{abstract}

ESTABLISHMENT DATA FROM BOTH THE UNITED STATES AND ABROAD uniformly reveal that as the proportion of female employees increases, so does the likelihood of payment by piece rates (for a review see Heywood, Hubler, and Jirjahn 1998). Yet representative individual data sources typically reveal either no association or that women are less likely to receive individual-based performance pay. In a study of 15 European countries, women were less likely to receive individual-based performance pay in four countries and more likely in only one (Cowling 2000, 2001). Using British data, Booth and Frank (1999) found that women were 8 percent less likely to receive individual performance pay than men. The individual-level studies typically use a broader dependent variable, which includes both piece rates and other seemingly similar forms of performance or contingent pay such as commissions and bonuses.

We hypothesize that labor force attachment and expected tenure play different roles in determining these other seemingly similar forms of performance pay. As a result, the relationship between gender and other forms of performance pay will differ from the relationship between gender and piece rates. Workers with lower labor force attachment and lower expected

* The authors' affiliations are, respectively, Department of Economics, Eastern Washington University, and Department of Economics and Graduate Program in Human Resources and Labor Relations, University of Wisconsin-Milwaukee. E-mail: lgeddes@ewu.edu and heywood@uwm.edu. We thank David I. Levine, the referees, and seminar participants at the University of Wisconsin at Milwaukee.

Industrial Relations, Vol. 42, No. 3 (July 2003). (C) 2003 Regents of the University of California Published by Blackwell Publishing, Inc., 350 Main Street, Malden, MA 02148, USA, and 9600 Garsington Road, Oxford, OX4 2DQ, UK. 
tenure will, on average, be sorted (by choice or not) into relatively low-skilled jobs requiring less investment in job- and employer-specific training. Such jobs among operatives and craft workers likely are paid by piece rates (Goldin 1986), but we suggest that such jobs among sales workers are unlikely paid by commission. Sales workers with short horizons will be sorted into positions with little scope for discretionary effort and investment in productspecific and relationship-specific skills. These jobs have no reason to reward sales through commissions because effort and skill accumulation will not respond.

After explicitly modeling the difference just highlighted, evidence from the National Longitudinal Survey of Youth (NLSY) cohorts shows that women in broad representative samples are indeed more likely to receive piece rates even as they are less likely to receive broader measures of performance pay. These two results persist simultaneously because of a very strong but not previously emphasized relationship that women are much less likely to be paid by commission and bonuses, all else equal. When examining the broader measure, the effect of gender on piece rates is offset by an opposing effect on commissions and bonus schemes.

Having confirmed this in a broad representative sample, we examine relevant occupational groups in detail. We show that commissioned sales workers compared with those not on commissions are more highly educated, invest in more training, work more hours, have greater tenure, are more likely to receive a pension, and earn higher wage income. They are also disproportionately male. At the same time, craft and operative workers who are paid piece rates compared with those not paid piece rates are more likely to be married, have more dependents, work fewer hours, have the same or less education and training, and earn the same or less income. They are also disproportionately female. These differences persist in our multivariate estimates of the determinants of commissions and piece rates within the respective occupations. They also persist after correcting for sample selection. Most important, among sales workers, women are less likely to receive commissions, and among craft and operative workers, women are more likely to receive piece rates.

By exploiting the panel nature of the NLSY more efficiently, estimates of the determinants of piece rates and commissions are provided. We create unbalanced panels within the sales and craft and operative subsamples by combining the 3 years in which the questions on performance pay are available. Recognizing that individual errors will be correlated across years, an error components model is estimated. While the estimations confirm the importance of accounting for such components, the role of gender does not change. 
The next section discusses the relationship between women and individual performance pay and presents a model designed to contrast the determinants of piece rates from those of commissions and bonuses. The third section formalizes the hypotheses by presenting a theoretical model. The fourth section describes the data, methodology, and basic results. The results within the relevant subsamples are presented in the fifth section. The sixth section expands the results by examining the panels and accounting for random effects, and this is followed by a summary and conclusion.

\section{Gender and Performance Pay}

The hypothesis that women are disproportionately paid by piece rates follows from two broad lines of reasoning. First, women traditionally have had shorter expected tenure and are, thus presumed, less motivated by deferred compensation. Under deferred compensation, workers are paid less than the value of their marginal product early in their tenure and more than the value of their marginal product late in their tenure. Workers receive the full value of their accumulated quasi-rents only if they complete longterm employment relationships (Lazear 1979, 1981). Piece rates reward workers immediately for increased productivity and should attract shorttenure workers and women in particular. Goldin (1986) confirms this logic using historical data showing that the supervisory costs of women paid by time rates were eight times higher then their piece-rate counterparts. This differential is substantially larger than that for men and indicates to Goldin that piece rates are particularly successful in reducing the monitoring cost of women workers.

Second, women traditionally have had lower labor force attachment. Women are more likely to be absent from work for their own illness or for the illness of a family member. They are more likely to restrict commuting time, total work hours, and their schedule (Corcoran and Duncan 1979; Goldin 1986). Even among the highly paid, women are more likely to have home responsibilities associated with children and the family (Wood, Corcoran, and Courant 1993) and more likely to require schedule flexibility (Beckmann 1998). Moreover, the presence of flexibility is a much stronger determinant of job satisfaction for women than for men (Bender, Donohue, and Heywood 2001). In turn, such flexibility is associated with jobs requiring lower levels of cooperative or team production (Deardorf and Stafford 1976; Alchian and Demsetz 1972). In such positions, low labor force attachment, such as being absent, imposes minimal costs because only 
the individual's output is lost, not that of an entire group of workers. ${ }^{1}$ Thus workers with low labor force attachment will be sorted into production characterized by individually based production. It is largely in these settings that individual output can be measured and piece rates devised (Goldin 1986; Heywood and Wei 1997). Thus women are sorted into production settings suited to individual piece rates. ${ }^{2}$

Following these two lines of reasoning, the proportion of females has been used routinely as a proxy for short expected tenure and lower labor force attachment in estimates of the contemporary determinants of piece rates [see Heywood, Hubler, and Jirjahn (1998) for a review of studies from a half dozen countries]. These lines of reasoning also have been appealed to by those examining the broader measures of individual performance pay using individual-level data sources (Booth and Frank 1999; Cowling 2000, 2001). The fact that the individual-level studies tend to show no or a negative association with gender has been seen as evidence against the anticipated role of expected tenure and labor force attachment and to result from superior controls for experience, children, and tenure in the individual-level data sources.

Yet the two lines of reasoning just described do not apply to the other seemingly similar forms of individual performance pay included in the broader measures. For example, even though commissions may appear to be a sales analogue to piece rates, we argue that they are not. Sales workers paid by commission are often in positions of contact with repeat customers, and both the customers and the firm depend on a long-term relationship. Thus a sales representative for a manufacturing firm needs to build a longterm relationship with the buyers for wholesale and retail firms. Less dramatically, a stockbroker paid by commission is usually successful only after developing a solid group of long-term repeat customers. In both these examples, the return on effort today may be realized only when sales are made in the future. It is because of these long-term relationships and the effort necessary to cultivate them that these sales workers can influence the volume and scope of sales and why a commission can be expected to motivate sales people. In contrast, a person at a sales counter has far less opportunity to build long-term relationships with customers and less ability to

\footnotetext{
${ }^{1}$ As an illustration, Duncan and Stafford (1980) contrast a typing pool in which an absent worker reduces output only by his or her own output and an assembly line in which the absence of a person at a specific station can eliminate all production from the line.

${ }^{2}$ Both Australian and German evidence shows that when the share of women workers in an establishment is high, the use of work groups, cooperative production, and the associated group-level payment schemes are less likely (Drago and Heywood 1995; Heywood and Jirjahn 2002).
} 
influence the number and size of sales. While it is true that there may be some repeat customers, there are usually too many customers to individualize the service, build relationships, and increase sales. ${ }^{3}$ This reverses predictions on which characteristics will be associated with being paid by commission. Sales workers paid commissions are likely to be in jobs that require longer tenure and more investment on the job. ${ }^{4}$ This is the opposite of the expectation for those paid piece rates. Accordingly, women should be less likely to be paid by commission. ${ }^{5}$

Similarly, the predictions associated with low labor force attachment also should be reversed when considering commissions. Sales workers on commission are often "on call" to the potential purchasers. Unlike classic piecerate jobs, such as stamping machine operatives (see Pencavel 1977), in which anytime the machine is available, the work can be done, sales work depends on the schedule of the potential purchasers. Understanding the needs of the purchaser, explaining the characteristics of the product, and customizing the sale require the cooperative effort of the buyer and the sales worker. Lower labor force attachment imposes greater costs in this circumstance than in one of counter sales. Thus the ability to influence the probability and size of the sale is associated with the need for greater labor force attachment and with the use of commissions. This also reverses the hypothesis taken from the piece-rate literature suggesting that women should be less likely to be paid by commissions. ${ }^{6}$

Unlike piece rates, bonus schemes are used where actual productivity cannot be measured easily. As Lazear (1996: Chap. 2) emphasized, when measuring productivity is difficult or impossible, supervisors monitor and reward effort. ${ }^{7}$ Such monitoring is demanded mostly in circumstances of team

\footnotetext{
${ }^{3}$ We recognize that there are some circumstances in which the sales person can influence the sale; however, repeat customers are often not important. Examples might include telemarketers or car sales people. Nonetheless, MacLeod and Parent (1999) conjecture that even for such circumstances it takes time before individuals doing commission work develop the skills and contacts necessary to reduce unwanted variability in their sales. This also suggests that only longer-term employees will be associated with commissions.

${ }^{4}$ As an illustration from our NLSY data, workers receiving commissions in finance, insurance, and real estate average 134 weeks of tenure, and those in wholesale trade average 144 weeks, both above, although not significantly, the average for the entire sample of 129 weeks.

${ }^{5}$ Thus, we know that nationally, males and females are employed in sales jobs almost equally but the type of sales job differs. Females tend to be in retail sales, including counter-type jobs, and males tend to be in on-the road direct sales and firm-to-firm sales (Blau et al. 1998).

${ }^{6}$ An obvious exception is that of real estate agents, who are disproportionately women and who usually are paid by commission.

${ }^{7}$ This does not deny that bonuses may be tied to an "objective" measure such as accounting results. Yet even here women may be less likely to receive bonuses because they are relatively underrepresented in the high-level jobs necessary to influence accounting results.
} 
production where individual productivity cannot be measured. ${ }^{8}$ Thus we anticipate that those with lower labor force attachment, including women, will be sorted out of bonus schemes. ${ }^{9}$

The contention that women sort out of teamwork and the fact that women have shorter expected tenure can be reinforcing. Cooperation can be increased through peer pressure in which team members influence the work behavior of an individual member. Yet creating this peer pressure depends on long-term employment relations and a long-lived team. Shorter tenure makes peer pressure difficult to develop (Kandel and Lazear 1992). For example, the mutual reinforcing necessary to overcome the free-rider problem in profit sharing is much more likely with long-term employees (Weitzman and Kruse 1990). Consequently, fully separating the influence of low labor force attachment and shorter expected tenure may well be impossible.

\section{A Model of Commissions and Piece Rates}

To derive specific implications, we extend the piece-rate-adoption model of Heywood, Siebert, and Wei (1997) to allow for differences in expected tenure and explicitly to consider commissions. ${ }^{10}$ Following that model, the monitoring cost of $L$ workers on time rates is $a_{i} L$, where $i=1$ for long-term workers, $i=2$ for short-term workers, and $a_{1}<a_{2}$ because deferred compensation is expected to be more successful with long-term workers (Goldin 1986). The monitoring costs for workers on piece rates or commissions is $F+g L$, where $g$ is the per-worker variable monitoring cost and $F$ is the fixed costs of establishing and administering a payment scheme (Brown and Medoff 1989). The maintained hypothesis is that one purpose of these schemes is to lower monitoring costs. Thus

$$
a_{2}>a_{1}>g
$$

\footnotetext{
${ }^{8}$ As an illustration, Seltzer (1998) examines the internal labor market at a large bank. The managerial and finance functions involve teamwork, effort is monitored, rewards are often deferred, and employees have very long tenure.

${ }^{9}$ Booth and Frank (1999) present an interesting alternative to this argument. They suggest that women are less likely to be paid by individual incentive schemes in Great Britain because they fear the discrimination that might be inherent in supervisors making judgments about effort. Yet, as Belman and Heywood (1988) noted a decade earlier, minorities might choose piece rates exactly because there is less scope for discrimination in the face of "objective" measures of productivity. This again highlights the importance of disaggregating the incentive variable. Fear of discrimination may push women toward piece rates and away from merit or bonus schemes, yet both are included in the typical broad measure of incentive pay.

${ }^{10}$ The work by Heywood, Siebert, and Wei (1997) is an extension of Lazear's (1986) original work.
} 
However, for a sufficiently small $L$, time rates may have lower per-worker total monitoring costs, that is, $F / L+g>a_{i}$.

To capture the difference between commissions and piece rates, we assume that the reward to effort on piece rates is immediate, whereas that from commissions is, to some degree, deferred. Thus it takes time to develop contacts and the trust needed to cultivate the long-term relationships that we posit are important in sophisticated sales jobs. Only in these jobs is there scope for sales people to expend effort in meaningful ways. The counter help at a store has less such scope than those selling jet engines. We capture this as there being two periods in which effort today is rewarded in commission jobs but only one period in piece-rate jobs.

Assuming a zero-profit condition, we follow Lazear (1986) by modeling worker behavior as maximizing the net surplus where the benefits are increased effort $E$ and the costs are the total per-worker monitoring cost and the cost of effort $C(E)$. Effort is measured by output, and the level of effort chosen by the worker on either piece rates or commissions is such that

$$
E=\arg _{E} \max \alpha E+\rho(1-\alpha) E-(F / L+g)-C(E)
$$

Here $\alpha$ is the share of the rewards from effort expended in period one that are captured in period one, with $(1-\alpha)$ being the share captured in the second period. The notion of expected tenure enters as $\rho$, the probability of remaining employed with the current employer in the second period. Alternatively, $\alpha$ could be interpreted as the share of rewards associated with high labor force attachment and $\rho$ as an indicator of labor force attachment varying from 0 to 1 . Under either interpretation, the following first-order condition determines the optimal level of effort $E^{*}$ :

$$
\alpha+\rho(1-\alpha)=C^{\prime}(E)
$$

Note that for workers on commissions, $\alpha<1, \partial E^{*} / \partial \alpha>0$. Thus the more deferred the compensation (or the greater the importance of high labor force attachment), the smaller is the effort, all else equal. ${ }^{11}$ This is distinct from our more basic point that those who place the greatest value on immediate rewards will be sorted out of commissions.

For time workers, the purpose of monitoring is to ensure a minimally acceptable level of effort $E_{M}$, and workers can chose any effort level above the minimum. Recognizing that increasing effort will not increase the reward for time rates, workers on time rates adopt the minimum. Thus time rates will be chosen over piece rates or commissions if and only if

\footnotetext{
"This follows from applying the implicit function theorem to Equation (3) and recognizing that the cost of effort generally is assumed to increase at an increasing rate, $C^{\prime \prime}(E)>0$.
} 
$426 /$ Lori A. Geddes and John S. Heywood

$$
(F / L+g)-a_{i}>\left[\alpha E^{*}+\rho(1-\alpha) E^{*}\right]-E_{M}-C\left(E^{*}\right)+C\left(E_{M}\right)
$$

A second-order Taylor expansion of $C\left(E_{M}\right)$ around $E^{*}$ yields the following:

$$
C\left(E_{M}\right)=C\left(E^{*}\right)+C^{\prime}\left(E^{*}\right)\left(E_{M}-E^{*}\right)+{ }_{1}^{1} C^{\prime \prime}\left(E^{*}\right)\left(E_{M}-E^{*}\right)^{2}
$$

Substituting Equation (4) into Equation (5), we get

$$
\begin{aligned}
& (F / L+g)-a_{i}>\alpha E^{*}+\rho(1-\alpha) E^{*}-E_{M}-C\left(E^{*}\right)+C\left(E^{*}\right) \\
& +C^{\prime}\left(E^{*}\right)\left(E_{M}-E^{*}\right)+1 /{ }_{2} C^{\prime \prime}\left(E^{*}\right)\left(E_{M}-E^{*}\right)^{2}
\end{aligned}
$$

Substituting Equation (3) into Equation (6) and simplifying yields the following:

$$
(F / L+g)-a_{i}>(1-\alpha)(\rho-1) E_{M}+{ }^{1} /{ }_{2} C^{\prime \prime}\left(E_{M}-E^{*}\right)^{2}
$$

Several predictions can be made. First, when the number of workers grows, payment schemes, of either type, are more likely as the left-hand side of Equation (7) shrinks. Second, short-term workers are more likely to be on piece rates. Piece rates are associated with immediate output and reward (or no return to high labor force attachment), $\alpha=1$. In this case, Equation (7) reduces to

$$
(F / L+g)-a_{i}>1 /{ }_{2} C^{\prime \prime}\left(E_{M}-E^{*}\right)^{2}
$$

The left-hand side is smaller and piece rates are more likely when $i=2$. This, in essence, is Goldin's (1986) argument that lower monitoring costs of short-term workers can be accomplished by paying piece rates. Third, workers with longer expected tenure (or higher labor force attachment) are more likely to be on commission, $\alpha<1$. As argued, sales jobs suitable for commission are likely to have a smaller value of $\alpha$ because of the importance of long-term relationships between buyers and sellers (and the importance of high labor force attachment). Taking the derivative of the right-hand side (RHS) of Equation (7) yields the following:

$$
\frac{\partial \operatorname{RHS}(7)}{\partial \rho}=(1-\alpha) E_{M}>0 \quad \forall \alpha<1
$$

Thus, for large values of $\rho$, the right-hand side of Equation (7) is larger, making payment by commission more likely. The fact that short-term workers are more costly to monitor on time rates is offset by the fact that those workers will not have a large effort response to commissions (or by the fact that workers with low attachment will not have a large effort response to commissions). We expect them to be sorted away from commissions because of the partially deferred nature of such payment schemes. Indeed, during training periods, the quotas for sales people paid by commission are often 
less, recognizing the time that it takes to establish clients. Thus, as we move to testing, we anticipate that many determinants of piece rates will be the opposite of those for commissions because variables associated with longerterm and more attached workers associate negatively with piece rates but positively with commissions.

\section{Data and Initial Results}

The NLSY distinguishes the type of performance pay received by the respondents. The primary question asks if the respondent receives payment directly tied to his or her individual performance. If yes, the respondent is asked whether this payment comes in the form of piece rates, commissions, or a bonus scheme. ${ }^{12}$ The answer to the first question provides a broad measure of individual-based performance pay similar to that used in other individuallevel studies. The fact that the broad measure is then broken down into three major alternatives allows us to test the contradictory predictions we hypothesize for the role of expected tenure, labor force attachment, and gender.

Since the dependent variables are binary, whether or not the respondent was paid piece rates, for example, all estimates will be fit to a cumulative normal distribution, a probit estimate:

$$
\operatorname{Prob}(Y=1)=\int_{-\infty}^{\beta^{\prime} x} \phi(t) d t=\Phi\left(\beta^{\prime} x\right)
$$

We recognize the limitations associated with using only a binary variable. For example, we have no information from the NLSY on what portion of a worker's total remuneration comes from a particular type of performance pay or how long a worker has been paid by that scheme. Nearly all the prior establishment- and individual-level studies share this difficulty.

An advantage to using individual data is the provision of worker characteristics not available in establishment surveys. The NLSY allows for a direct measure of work experience rather than proxies based on age (Ewing 1996). This may be particularly important because women convert a smaller portion of potential experience into actual experience. In addition, superior variables can proxy short tenure and labor force attachment, such as the number of children in the home. Establishment surveys generally do not include these variables.

\footnotetext{
12 The question also allows positive responders to identify their form of pay as tips, stock options, or other. Very few workers identify these forms of payment.
} 
The NLSY began interviewing 12,686 people between the ages of 14 and 21 in 1978. In the years 1988-1990, the NLSY collected data on performance pay, as outlined earlier. Our cross-sectional estimates use the data from 1988 , but our panel estimates make use of all three years in which the performance-pay data were collected. In 1988, there were 10,465 respondents. Restricting the sample to individuals employed by the private sector, not in agriculture, not enrolled in school, and for whom full data are available reduces the sample to 5581 individuals. Since the cross-sectional results are similar for all three years, only those for 1988 are presented here.

The estimation strategy will be to first present sample-wide estimates of the determinants of the broad performance-pay indicator and its three constituent elements. This allows an initial contrast between the determinants of piece rates and other forms of individual performance pay that follows previous studies. Since the specific types of performance pay are heavily concentrated in particular occupations, two subsamples will next be investigated in detail. The determinants of piece rates will be estimated in a subsample of craft and operative workers, and the determinants of commissions will be estimated in a subsample of sales workers. These latter estimations provide the clearest test of whether or not lower labor force attachment, expected tenure, and gender differ in the role they play in determining piece rates and commissions.

The explanatory variables include basic worker characteristics and job characteristics. These include race, age, gender, Armed Forces Qualifying Test (AFQT) scores, actual experience, tenure, years of schooling, whether or not the respondent is a supervisor, union status, marital status, establishment size, and occupational dummies. ${ }^{13}$ The sample means and definitions of the variables are presented in Table 1. They reflect the age of the cohort with relatively short tenure and high job turnover. Thus we group tenure into three broad categories: less than 12 months, 12 to 60 months, and more than 60 months. The experience, education, and AFQT variables control for ability. Unions generally oppose performance pay because it violates the link between the job and the wage, undermining the solidarity wage. ${ }^{14}$ The nature of the job (its industry and occupation) helps determine whether it is suitable for particular types of performance-pay schemes (whether or not pieces can be counted, for instance).$^{15}$

In addition, a series of variables is used that helps proxy labor force attachment and expected tenure. These include the share of hours worked

\footnotetext{
${ }^{13}$ Broad industrial dummies also were included, but doing so did not alter any of the relevant results.

${ }^{14}$ For review of the history of union concerns with performance pay and profit sharing, see Jacoby (1997:236-262).

${ }^{15}$ The series of dummies follows the broad 1980 Census classification for both industries and occupations.
} 
TABLE 1

Descriptive Statistics $^{a}$

\begin{tabular}{|c|c|c|}
\hline Variable & Description & Mean \\
\hline & Dependent Variables & \\
\hline Piece rate & Equals 1 if the person was paid a piece rate & $\begin{array}{c}0.0359 \\
(0.1862)\end{array}$ \\
\hline Commission & Equals 1 if the person was paid a commission & $\begin{array}{c}0.0594 \\
(0.2363)\end{array}$ \\
\hline Bonus & Equals 1 if the person was paid a bonus & $\begin{array}{l}0.135 \\
(0.3418)\end{array}$ \\
\hline \multirow[t]{2}{*}{ Incentive pay } & Equals 1 if person was paid piece rate, commission, or bonus & $\begin{array}{c}0.2074 \\
(0.4055)\end{array}$ \\
\hline & Independent Variables & \\
\hline Female & Equals 1 if the person is female & $\begin{array}{c}0.4776 \\
(0.4995)\end{array}$ \\
\hline Age & Person's age at time of interview & $\begin{array}{l}27.02 \\
(2.248)\end{array}$ \\
\hline White & Equals 1 if the person is white & $\begin{array}{c}0.6886 \\
(0.4631)\end{array}$ \\
\hline Married & Equals 1 if the person is currently married & $\begin{array}{l}0.48 \\
(0.4996)\end{array}$ \\
\hline Education & The number of years of schooling completed & $\begin{array}{l}12.6079 \\
(2.2489)\end{array}$ \\
\hline AFQT & The 1989 score on the Air force Qualifying Test & $\begin{array}{l}43.0 \\
(29.27)\end{array}$ \\
\hline Supervisor & Equals 1 if the person supervises others on the job & $\begin{array}{c}0.3767 \\
(0.4846)\end{array}$ \\
\hline Size & $\begin{array}{l}\text { The natural log of the number of employees for current or most } \\
\text { recent employer }\end{array}$ & $\begin{array}{l}3.849 \\
(2.0402)\end{array}$ \\
\hline Spells not working & The number of periods not working since last interview & $\begin{array}{r}0.4874 \\
(0.7453)\end{array}$ \\
\hline Union & Equals 1 if a union represents the person & $\begin{array}{c}0.1323 \\
(0.3388)\end{array}$ \\
\hline Home hours & The share of hours worked at home per week & $\begin{array}{c}0.0203 \\
(0.1002)\end{array}$ \\
\hline Employer training & Equals 1 if the employer provides education and training & $\begin{array}{l}0.382 \\
(0.4859)\end{array}$ \\
\hline Dependents & The number of dependents & $\begin{array}{c}0.7951 \\
(1.1165)\end{array}$ \\
\hline Full-time & Equals 1 if the person is working 35 or more hours per week & $\begin{array}{r}0.7819 \\
(0.413)\end{array}$ \\
\hline Young child & Equals 1 if the youngest child at home is 6 yrs or younger & $\begin{array}{c}0.3594 \\
(0.4799)\end{array}$ \\
\hline Experience & The number of weeks worked for all past employers & $\begin{array}{r}54.0063 \\
(94.1881)\end{array}$ \\
\hline Low tenure & $\begin{array}{l}\text { Equals } 1 \text { if the number of months of tenure with current employer is } \\
\text { less than } 12 \text { months }\end{array}$ & $\begin{array}{r}0.3113 \\
(0.4631)\end{array}$ \\
\hline Medium tenure & $\begin{array}{l}\text { Equals } 1 \text { if the number of months of tenure with current employer is } \\
\text { between } 12 \text { and } 60\end{array}$ & $\begin{array}{c}0.4862 \\
(0.4998)\end{array}$ \\
\hline
\end{tabular}


TABLE 1

CONTINUED

\begin{tabular}{llc}
\hline \hline Variable & \multicolumn{1}{c}{ Description } & Mean \\
\hline High tenure & Equals 1 if the number of months of tenure with current employer is & 0.2025 \\
& greater than 60 & $(0.4019)$ \\
Expectations & Equals 1 if the person expects to have the ability to obtain their & 0.2221 \\
& planned occupation & $(0.4157)$ \\
\hline
\end{tabular}

${ }^{a}$ Standard deviations are in parenthesis; statistics are for private sector in 1988, with $N=6621$.

at home, the number of dependents, and if there is a young child at home. We take each of these to be related to labor force attachment and, potentially, to gender. As an additional indicator, we include a variable measuring the number of previous periods the respondent was not working. Again, the fewer the number, the greater is the labor force attachment we anticipate.

A measure of employer-provided training opportunities proxies expected tenure and is considered an indicator of an internal labor market (Siebert and Addison 1991). An employer is unlikely to invest in workers planning to leave the firm soon, and a worker is not likely to seek training if he or she is planning to leave the labor market in the near future. Training is likely to be associated with both expected tenure and gender. ${ }^{16}$ Employer-provided pension also proxies longer expected tenure. Pensions are a form of deferred compensation bonding the worker and firm. Defined-benefit plans in particular are well recognized as gaining most of their value in the final years of a worker's tenure. In addition, we use a variable from an earlier wave (1982) identifying whether or not the respondent felt he or she had the necessary ability to reach his or her desired occupational goals. We take this to be a measure of expectations, with those answering "yes" having higher expectations for themselves and their career success. We anticipate that workers with greater ability and higher expectations will be sorted into longer-term relationships that involve greater on-the-job investment and that they will have greater labor force attachment.

Table 2 presents the full sample estimates for each of the indicators of performance pay. The first column presents the determinants of the broad performance-pay indicator. Women are less likely to receive such incentive payments. This is in accord with the results from other individual data sources. Also matching the results of earlier studies, more educated workers

\footnotetext{
${ }^{16}$ Indeed, Lynch (1992) finds that women receive less on-the-job training then men and recognizes that one of the critical reasons may be lower expected tenure.
} 
TABLE 2

Determinants of InCENTIVE PAY, 1988 NLSY

\begin{tabular}{|c|c|c|c|c|}
\hline Variable & Incentive Pay ${ }^{a, b}$ & Piece Rate ${ }^{a, b}$ & Commission $^{a, b}$ & Bonus $^{a, b}$ \\
\hline Female & $\begin{array}{c}-0.0371 * * * \\
(0.0124)\end{array}$ & $\begin{array}{c}0.0146 * * * \\
(0.0045)\end{array}$ & $\begin{array}{c}-0.0247^{* * *} \\
(0.0057)\end{array}$ & $\begin{array}{c}-0.0443^{* * *} \\
(0.0100)\end{array}$ \\
\hline Age & $\begin{array}{l}-0.0026 \\
(0.0025)\end{array}$ & $\begin{array}{c}0.0011 \\
(0.0008)\end{array}$ & $\begin{array}{c}0.0003 \\
(0.0011)\end{array}$ & $\begin{array}{c}-0.0054^{* * *} \\
(0.0020)\end{array}$ \\
\hline White & $\begin{array}{c}0.0043 \\
(0.0123)\end{array}$ & $\begin{array}{l}-0.0001 \\
(0.0039)\end{array}$ & $\begin{array}{c}0.0089 \\
(0.0053)\end{array}$ & $\begin{array}{r}-0.0065 \\
(0.0102)\end{array}$ \\
\hline Married & $\begin{array}{c}0.0025 \\
(0.0124)\end{array}$ & $\begin{array}{c}0.0004 \\
(0.0041)\end{array}$ & $\begin{array}{l}-0.0035 \\
(0.0056)\end{array}$ & $\begin{array}{c}0.0031 \\
(0.0100)\end{array}$ \\
\hline Education & $\begin{array}{l}0.0049^{*} \\
(0.0029)\end{array}$ & $\begin{array}{l}-0.0001 \\
(0.0010)\end{array}$ & $\begin{array}{l}0.0024^{*} \\
(0.0013)\end{array}$ & $\begin{array}{c}0.0010 \\
(0.0023)\end{array}$ \\
\hline AFQT & $\begin{array}{c}0.0002 \\
(0.0002)\end{array}$ & $\begin{array}{c}0.0001 \\
(0.0001)\end{array}$ & $\begin{array}{l}-0.0001 \\
(0.0001)\end{array}$ & $\begin{array}{c}0.0002 \\
(0.0001)\end{array}$ \\
\hline Supervisor & $\begin{array}{c}0.0485^{* * * *} \\
(0.0121)\end{array}$ & $\begin{array}{c}-0.0125^{* * *} \\
(0.0038)\end{array}$ & $\begin{array}{l}-0.0070 \\
(0.0050)\end{array}$ & $\begin{array}{c}0.0883^{* * *} \\
(0.0103)\end{array}$ \\
\hline Size & $\begin{array}{c}-0.0113^{* * *} \\
(0.0030)\end{array}$ & $\begin{array}{c}0.0014 \\
(0.0010)\end{array}$ & $\begin{array}{c}-0.0102^{* * * *} \\
(0.0014)\end{array}$ & $\begin{array}{c}-0.0062^{* * *} \\
(0.0024)\end{array}$ \\
\hline Spells not working & $\begin{array}{r}-0.0100 \\
(0.0101)\end{array}$ & $\begin{array}{l}-0.0011 \\
(0.0032)\end{array}$ & $\begin{array}{r}-0.0023 \\
(0.0043)\end{array}$ & $\begin{array}{l}-0.0072 \\
(0.0083)\end{array}$ \\
\hline Union & $\begin{array}{l}-0.0234 \\
(0.0159)\end{array}$ & $\begin{array}{l}-0.0053 \\
(0.0042)\end{array}$ & $\begin{array}{c}-0.0182^{* *} \\
(0.0064)\end{array}$ & $\begin{array}{c}0.0052 \\
(0.0138)\end{array}$ \\
\hline Home hours & $\begin{array}{c}0.1754^{* * * *} \\
(0.0544)\end{array}$ & $\begin{array}{c}0.0203 \\
(0.0180)\end{array}$ & $\begin{array}{c}0.0621^{* * * *} \\
(0.0191)\end{array}$ & $\begin{array}{c}0.0688 \\
(0.0459)\end{array}$ \\
\hline Employer training & $\begin{array}{c}0.0661^{* * *} \\
(0.0130)\end{array}$ & $\begin{array}{c}-0.0077^{*} \\
(0.0040)\end{array}$ & $\begin{array}{c}0.0222 * * * \\
(0.0062)\end{array}$ & $\begin{array}{c}0.0668^{* * * *} \\
(0.0107)\end{array}$ \\
\hline Dependents & $\begin{array}{c}0.0118 * * * \\
(0.0059)\end{array}$ & $\begin{array}{c}0.0059 * * * \\
(0.0017)\end{array}$ & $\begin{array}{c}0.0008 \\
(0.0027)\end{array}$ & $\begin{array}{c}0.0014 \\
(0.0049)\end{array}$ \\
\hline Full-time & $\begin{array}{c}0.0453^{* * *} \\
(0.0139)\end{array}$ & $\begin{array}{c}0.0018 \\
(0.0048)\end{array}$ & $\begin{array}{c}0.0091 \\
(0.0059)\end{array}$ & $\begin{array}{l}0.0291^{* *} \\
(0.0113)\end{array}$ \\
\hline Young child & $\begin{array}{c}-0.0305 * * * \\
(0.0139)\end{array}$ & $\begin{array}{c}-0.0081^{*} \\
(0.0041)\end{array}$ & $\begin{array}{l}-0.0053 \\
(0.0063)\end{array}$ & $\begin{array}{l}-0.0132 \\
(0.0113)\end{array}$ \\
\hline Experience & $\begin{array}{l}-7.21 \mathrm{E}-05 \\
(6.49 \mathrm{E}-05)\end{array}$ & $\begin{array}{l}-3.49 \mathrm{E}-05 \\
(2.46 \mathrm{E}-05)\end{array}$ & $\begin{array}{c}3.58 \mathrm{E}-05 \\
(2.58 \mathrm{E}-05)\end{array}$ & $\begin{array}{l}-7.15 \mathrm{E}-05 \\
(5.32 \mathrm{E}-05)\end{array}$ \\
\hline Medium tenure & $\begin{array}{l}0.0336 * * \\
(0.0165)\end{array}$ & $\begin{array}{c}0.0060 \\
(0.0055)\end{array}$ & $\begin{array}{c}0.0073 \\
(0.0070)\end{array}$ & $\begin{array}{c}0.0186 \\
(0.0136)\end{array}$ \\
\hline $\begin{array}{l}\text { High tenure } \\
\text { Expectations }\end{array}$ & $\begin{array}{c}0.0121 \\
(0.0215) \\
0.0231^{*} \\
(0.0135)\end{array}$ & $\begin{array}{c}0.0062 \\
(0.0080) \\
-0.0047 \\
(0.0043)\end{array}$ & $\begin{array}{c}0.0004 \\
(0.0093) \\
0.0140^{* *} \\
(0.0064)\end{array}$ & $\begin{array}{c}0.0022 \\
(0.0172) \\
0.0186^{*} \\
(0.0109)\end{array}$ \\
\hline Occupations & Yes & Yes & Yes & Yes \\
\hline Sample size & \multicolumn{4}{|c|}{5581} \\
\hline Observed $P$ & 0.2104 & 0.0357 & 0.0600 & 0.1380 \\
\hline Predicted $P$ & 0.1968 & 0.0211 & 0.0363 & 0.1192 \\
\hline$\chi^{2}$ & 347.71 & 227.52 & 479.72 & 353.26 \\
\hline Pseudo $R^{2}$ & 0.0606 & 0.1325 & 0.1893 & 0.0789 \\
\hline
\end{tabular}

${ }^{a}$ All coefficients have been transformed to the partial derivative or marginal effect, so the constant is not presented.

${ }^{b}$ Standard errors are in parentheses.

*** Significance at $1 \%$ level.

** Significance at $5 \%$ level.

*Significance at $10 \%$ level. 


\section{2 / Lori A. Geddes And John S. Heywood}

and supervisors are more likely to receive performance pay. ${ }^{17}$ Also matching Cowling (2001), establishment size is a negative influence of the probability of performance pay. High expectations, employer training, the number of dependents, the share of home hours, and medium tenure are all significant partial correlates with the incidence of performance pay. Yet this pattern of results is not representative of the determinants of the specific forms of performance pay.

The contrasts in determinants are numerous. Most coefficients take opposite signs as determinants of commissions from those they take as determinants of piece rates. Women are positively associated with piece rates (as the establishment studies suggest), whereas they are negatively associated with both commissions and bonuses. Thus previous results using the broad performance-pay variable would appear to be driven by those for commissions and bonuses. Both more educated workers and those with employer training are more likely to receive commissions but not to receive piece rates. While supervisors are more likely to receive bonuses, they are less likely to receive piece rates. Those with more dependents are more likely to receive piece rates but no more likely to receive commissions or bonuses. Indeed, none of the significant coefficients in the piece-rate equation is matched by significant coefficients of the same sign in the commission or bonus equations and vice versa. In short, the determinants of the underlying forms of performance pay differ, and the variables associated with higher expected tenure and labor force attachment are negative determinants of piece rates but positive determinants of the other forms of performance pay.

\section{Piece Rates and Commissions in the Subsamples}

The vast majority of all piece rates are paid to craft and operative workers. In our sample, more than three-fourths of those paid by piece rates are such workers. Similarly, despite the fact that sales workers comprise only about one-tenth of our sample, they account for more than half of all workers paid by commission. The broad general samples of the preceding section include many occupations in which virtually no workers are paid by either piece rates or commissions. Thus most of the individuals in that

\footnotetext{
${ }^{17}$ Cowling (2001) shows that managerial workers and those with degrees are more likely to receive a combination of wage and performance-related pay than to only receive a wage. Booth and Frank (1999) show that managerial workers and those who complete 0 levels are more likely to receive individual performance-related pay.
} 
sample do not directly face the sorting assumed in the earlier estimations. In order to focus on workers who do face such sorting, we estimate the determinants of commissions within the subsample of sales workers and the determinants of piece rates within the subsample of craft and operative workers.

As a first step, we examine the difference in means between those who do and do not receive performance pay for a series of critical determinants. Our theoretical work suggests that measures of human capital, labor force attachment, and expected tenure should be larger among those on commissions even as they are smaller among those on piece rates. Table 3 presents the respective means.

The results for sales workers are in the first three columns and present a dramatic picture. In virtually every case, the raw difference fits the theory. ${ }^{18}$ Workers on commissions have more education, are more likely married, have more experience, are less likely to have low tenure, have higher AFQT scores, are more likely to have training, have fewer dependents, are more likely to be white, work more hours, have higher earnings, have higher expectations, and are more likely to be full-time workers. Many, but not all, of these differences are statistically significant. More generally, the odds that by chance only 2 or fewer of the 16 differences in Table 3 would take on values that contradict theory (high tenure and, perhaps, size) is only twotenths of 1 percent. ${ }^{19}$ This appears to be a strong indication that commission workers have greater human capital, labor force attachment, and expected tenure when compared with their counterparts in sales not paid by commission.

The comparison with piece rates is provided by columns 4,5 , and 6 in Table 3. As seen, the sign of the difference is often reversed. Piece-rate workers have less education, less experience, are less likely to have training, have more dependents, work fewer hours, have lower earnings, have lower expectations, and are less likely to work full time when compared with their counterparts not paid by piece rates. Again, a number of these differences are individually statistically significant, but it is the general pattern, and its stark contrast with commissions, that is most persuasive. There are no significant differences in both subsamples taking the same sign, but there are three significant differences in both subsamples taking opposite signs. In short, within the two subsamples, the sorting appears to be happening along nearly opposite lines.

\footnotetext{
${ }^{18}$ We thank David Levine for suggesting these comparisons.

19 This is derived from the binomial distribution assuming that the probability of any individual difference being either positive or negative is one-half.
} 


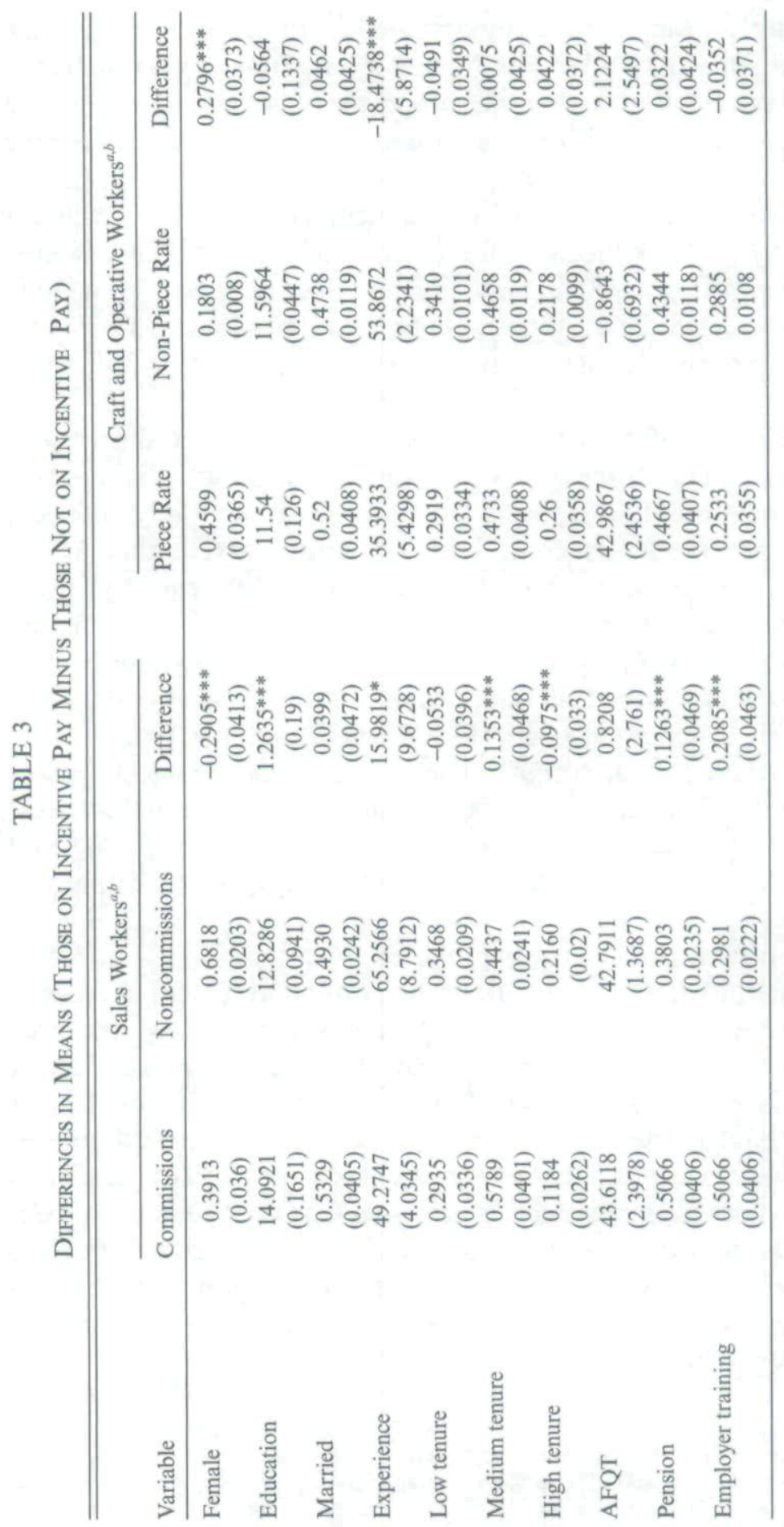




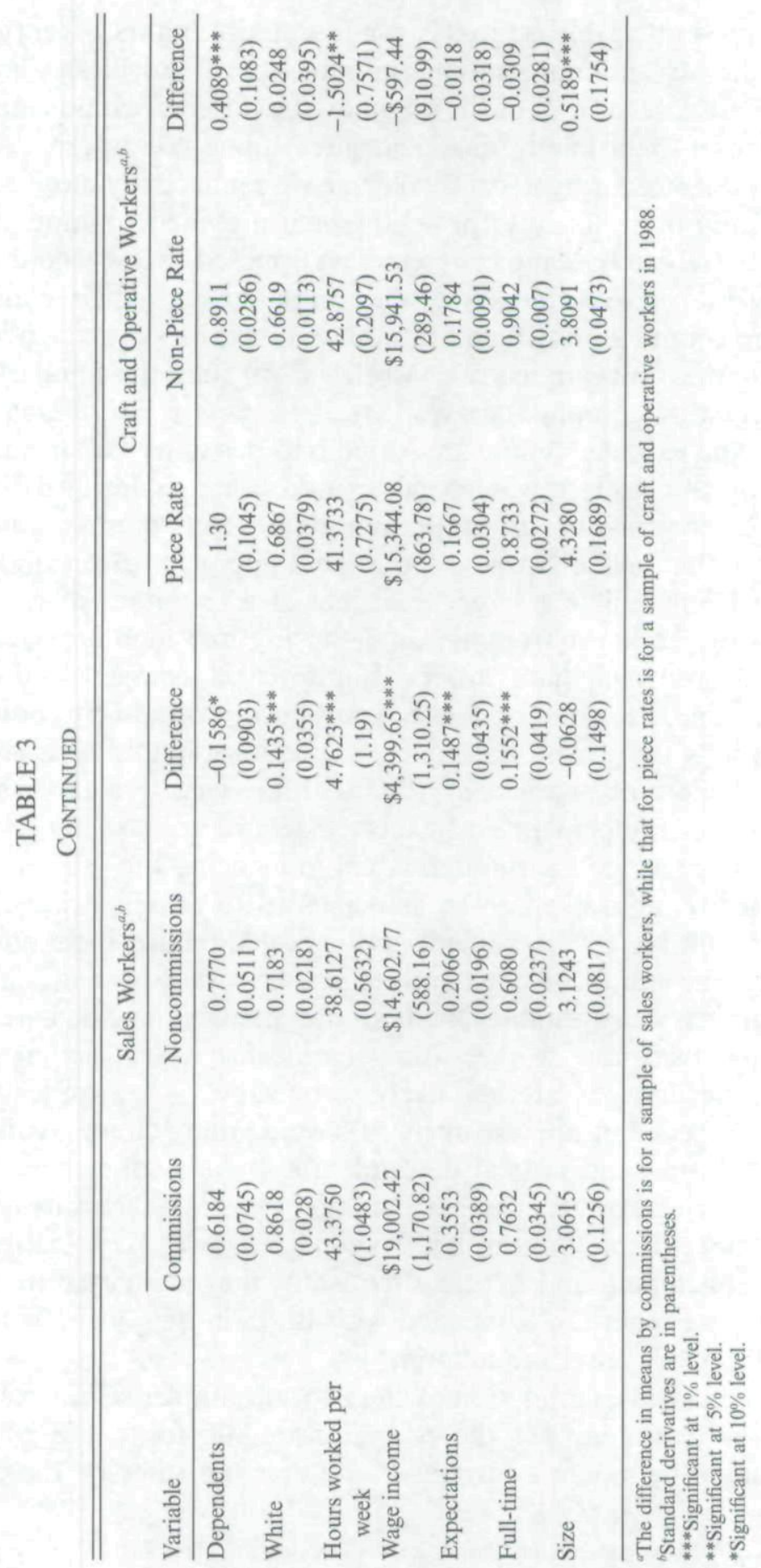


We now present probit estimates for the determinants of performance pay within the two subsamples using the same set of variables as used in the broad sample. As seen in Table 4, many of the differences indicated by the means carry over to the multivariate estimates. Among sales workers, those who receive commissions are significantly older, have significantly more education, are significantly more likely to have employer provided training, are significantly more likely to have medium tenure as opposed to low tenure, and have significantly higher expectations when compared with their counterparts not receiving commissions. In addition, union members are much less likely to receive commissions among sales workers. ${ }^{20}$ In sum, the significant determinants suggest that among sales workers, those with greater human capital, attachment, and expected tenure are sorted into positions with commissions.

Confirming this notion, women sales workers are significantly less likely to be paid by commission. From the marginal effects presented in Table 4 it is apparent that gender is one of the most important determinants. The influence of being female is larger than that of a few more years of education, of having employer training, or of having had high expectations. To the extent that women have lower labor force attachment and expected tenure, they appear to be sorted away from positions paid by commissions. This contradicts those who consider commissions simply as a sales work equivalent of piece rates. Instead, it fits with the view that those sales jobs requiring greater attachment and expected tenure are also those in which there is the most scope for the individual influencing the sale. As a result, commissions are more likely to be associated with those worker characteristics linked with higher attachment and expected tenure, including gender.

Again, the subsample of craft and operative workers provides a contrast and confirms the many establishment studies focusing on the determinants of piece rates. Piece-rate workers have significantly less experience, significantly more dependents, are less likely to be supervisors, are less likely to be union members, but are less likely to have a young child. Again, gender emerges as a large and critical determinant. In this subsample, however, women are sorted toward the performance pay of piece rates. This fits Goldin's (1986) original notion that women have lower expected tenure and labor force attachment and that, consequently, they are sorted toward individual piece rates that are associated with little on-the-job investment and little cooperative or team production.

While the detailed examination of the two subsamples reinforces the findings from the broad sample, the estimates are subject to the potential of selection bias. The workers attracted to either the sales or the craft and

\footnotetext{
${ }^{20}$ The share of sales workers unionized in our sample is only 7.9 percent.
} 
TABLE 4

Determinants of Piece Rates and Commissions in Relevant Occupations, 1988 NLSY

\begin{tabular}{|c|c|c|c|}
\hline Variable & $\begin{array}{c}\text { Commission }{ }^{a, c} \\
\text { (Sales Occupations) }\end{array}$ & $\begin{array}{c}\text { Piece Rate }{ }^{a, c} \\
\text { (Craft and Operative Occupations) }\end{array}$ & $\begin{array}{c}\text { Piece Rate }{ }^{b, c} \\
\text { (Selection Model) }\end{array}$ \\
\hline \multirow[t]{2}{*}{ Female } & $-0.1253^{* * *}$ & $0.0952^{* * *}$ & $1.0416^{* * *}$ \\
\hline & $(0.0438)$ & $(0.0209)$ & $(0.1512)$ \\
\hline \multirow[t]{2}{*}{ Age } & $0.0173^{* *}$ & 0.0039 & 0.0271 \\
\hline & $(0.0087)$ & $(0.0025)$ & $(0.0174)$ \\
\hline \multirow[t]{2}{*}{ White } & 0.0619 & 0.0081 & 0.0346 \\
\hline & $(0.0429)$ & $(0.0117)$ & $(0.0848)$ \\
\hline \multirow[t]{2}{*}{ Married } & -0.0343 & 0.0047 & 0.0293 \\
\hline & $(0.0424)$ & $(0.0129)$ & $(0.0863)$ \\
\hline \multirow[t]{2}{*}{ Education } & $0.0282^{* * *}$ & 0.0016 & $0.1092^{* * *}$ \\
\hline & $(0.0101)$ & $(0.0031)$ & $(0.0396)$ \\
\hline \multirow[t]{2}{*}{ AFQT } & 0.0005 & 0.0002 & 0.0009 \\
\hline & $(0.0006)$ & $(0.0002)$ & $(0.0013)$ \\
\hline \multirow[t]{2}{*}{ Supervisor } & -0.0575 & $-0.0303^{* *}$ & $-0.2079 * *$ \\
\hline & $(0.0389)$ & $(0.0115)$ & $(0.0962)$ \\
\hline \multirow[t]{2}{*}{ Size } & -0.0021 & 0.0023 & -0.0024 \\
\hline & $(0.0117)$ & $(0.0033)$ & $(0.0241)$ \\
\hline \multirow[t]{2}{*}{ Spells not working } & 0.0093 & -0.0033 & -0.0207 \\
\hline & $(0.0311)$ & $(0.0098)$ & $(0.0656)$ \\
\hline \multirow[t]{2}{*}{ Union } & $-0.1907 * * *$ & $-0.0272^{* *}$ & $-0.4099^{* * *}$ \\
\hline & $(0.0420)$ & $(0.0119)$ & $(0.1136)$ \\
\hline \multirow[t]{2}{*}{ Home hours } & $0.8738^{* * *}$ & -0.0524 & -0.3655 \\
\hline & $(0.1907)$ & $(0.1448)$ & $(0.9613)$ \\
\hline \multirow[t]{2}{*}{ Employer training } & $0.0908^{* *}$ & -0.0136 & -0.9051 \\
\hline & $(0.0436)$ & $(0.0125)$ & $(0.0915)$ \\
\hline \multirow[t]{2}{*}{ Dependents } & 0.0027 & $0.0173^{* * *}$ & $0.0846 * *$ \\
\hline & $(0.0238)$ & $(0.0050)$ & $(0.0435)$ \\
\hline \multirow[t]{2}{*}{ Full-time } & 0.0221 & -0.0158 & -0.0908 \\
\hline & $(0.0455)$ & $(0.0203)$ & (0.1199) \\
\hline \multirow[t]{2}{*}{ Young child } & 0.0071 & $-0.0288^{* *}$ & $-0.2114^{* *}$ \\
\hline & $(0.0484)$ & $(0.013)$ & $(0.0999)$ \\
\hline \multirow[t]{2}{*}{ Experience } & $2.35 \mathrm{E}-04$ & $-1.35 \mathrm{E}-04^{*}$ & -0.0009 \\
\hline & (2.12E-04) & $(8.02 \mathrm{E}-05)$ & $(0.0005)$ \\
\hline \multirow[t]{2}{*}{ Medium tenure } & $0.1036^{* *}$ & 0.0135 & 0.0983 \\
\hline & $(0.0529)$ & $(0.0175)$ & $(0.116)$ \\
\hline \multirow[t]{2}{*}{ High tenure } & -0.0635 & 0.0172 & 0.1086 \\
\hline & $(0.0633)$ & $(0.0241)$ & $(0.1469)$ \\
\hline \multirow[t]{2}{*}{ Expectations } & $0.1199^{* * *}$ & 0.0067 & 0.0587 \\
\hline & $(0.0464)$ & $(0.0155)$ & $(0.0991)$ \\
\hline Sample size & 592 & 1982 & 1981 \\
\hline Observed $P$ & 0.2635 & 0.0782 & $\mathrm{~N} / \mathrm{A}$ \\
\hline Predicted $\boldsymbol{P}$ & 0.2148 & 0.0643 & N/A \\
\hline$\rho$ & N/A & N/A & $-0.6167^{* *}$ \\
\hline & & & $(0.1839)$ \\
\hline$\chi^{2}$ & $144.92 * * *$ & $88.27 * * *$ & $165.47^{* * * *}$ \\
\hline Pseudo $R^{2}$ & 0.2122 & 0.0812 & N/A \\
\hline
\end{tabular}

all coefficients have been transformed to the partial derivative or marginal effect, so the constant is not presented.

${ }^{b}$ For the selection model, raw coefficients are presented.

'Standard errors are in parentheses.

$* * *$ Significance at $1 \%$ level.

${ }^{* *}$ Significance at $5 \%$ level.

* Significance at $10 \%$ level. 


\section{8 / Lori A. Geddes AND JoHn S. Heywood}

operative occupations may not be representative of the full sample in critical dimensions. These dimensions may well be unmeasured but may be associated with both gender and the chance of receiving performance pay. In these circumstances, the estimated role of gender within the subsamples may be biased (Heckman 1979). To address this concern, we reestimate the probit equations within each subsample, adjusting for sample selection. Following Van de Ven and Van Pragg (1981), we use a selection equation for the entire sample to determine, for instance, whether an individual is a sales worker. This is estimated jointly with the probability of being paid by commission among those in the sales subsample. In the face of selection bias, the consequence of the joint estimation is coefficient estimates for that second equation that are consistent and asymptotically efficient.

Estimation of the maximum-likelihood probit with selection yields dramatically different results for the two subsamples but does not at all change our basic conclusions. When estimating many variants of the selection equation for being a sales worker simultaneously with the variables indicated in Table 4 for being paid by commission, absolutely no evidence of a selection effect could be found. The likelihood-ratio test for independence could never be rejected. The coefficient $\rho$, the extent of correlated errors between the selection and commission equations, failed even to approach significance. Thus there is nothing to be gained by correcting for selection, and the estimates for commissions in Table 4 should be used.

On the other hand, the importance of selection is confirmed when correcting the piece-rate estimate for selection into the craft and operative occupations. As might be anticipated, craft and operative workers are more likely to be men, to be unionized, and to work in large establishments. They are less educated but more likely to have dependents. We would be pleased to provide the variants of the selection system we estimated but report one as a representative illustration. The selection equation was identified by including gender, education, race, union status, establishment size, number of dependents, experience, presence of a young child, whether or not the job required routine contact with other people, tenure, and the number of different jobs. The assumption of independence between that selection equation and the estimation of piece rates (assumption $\rho=0$ ) was rejected with a $\chi^{2}(1)=5.56$ and an associated probability value of 0.018 . The resulting estimation of the determinants of piece rates among the craft and operative workers is presented in the third column of Table $4 .^{21}$

As is apparent, the general nature of the results continues to mirror that which did not account for selection. While some levels of significance have

\footnotetext{
${ }^{21}$ The results from the selection equation are available on request.
} 
changed, the basic results remain in place. Perhaps most crucially, women remain significantly more likely to be paid by piece rates. Indeed, while the levels of significance of many of the determinants decreased, that of gender actually increased substantially. Accounting for selection only reinforces the finding that women are less likely to be paid by piece rates. Put somewhat differently, if a random selection of workers was drawn to the craft and operative occupations, women would be even more likely to be paid by piece rates than indicated by the selected sample of workers. Accounting for selection does not change the basic conclusion that the sorting appears to occur along roughly opposite lines for the two forms of performance pay, commissions, and piece rates.

\section{Panel Estimates}

Additional estimation uses the full information from the NLSY, including all three years (1988-1990) in which the performance-pay questions were asked. The potential self-selection of workers into piece rates or commissions highlights the importance of accounting for worker specific effects in examining the role of gender. When using establishment data from Australia, Brown and Heywood (2001) exploit an establishment panel to control for fixed effects at the establishment level in order to isolate the role of gender (changes in the percentage of workers who were women) over time. While such effects were important, confirming them is not possible with individual data in which the individual exhibits no variation in gender across time.

Nonetheless, individual specific error components (random effects) can be captured using the panel nature of NLSY and estimating the determinants of being paid by piece rates both across time and across individuals. This necessitates capturing the potential error structure introduced by using three waves in the pooled estimates. A random-error component may exist that is associated with each respondent but invariant over time. Failure to account for this error component can lead to biased standard errors and erroneous measures of statistical significance. Butler and Moffit (1980) provide a probit model that has the same structure as the more traditional random-effects generalized least squares estimation. This "random-effects probit" accounts for the individual-level error component and provides corrected estimates of the standard errors. ${ }^{22}$

Estimating the random-effects probit for our unbalanced panel reproduces and actually strengthens many of the fundamental results. Comparing the

\footnotetext{
${ }^{22}$ The estimation was performed in Stata 6.0. Parent (1999) provides an example of correcting for individual fixed effects when measuring the influence of piece rates on wages.
} 
estimates in Table 5 with those from Table 4, many variables have the same sign and level of significance. As column 1 shows, the more educated, the older, and those with employer-provided training remain more likely to be paid by commission. The AFQT test is now statistically significant and in the anticipated direction. Workers with higher scores are more likely to be paid by commission. The coefficient on share of hours worked at home gains statistical significance, but expectations lose significance. Perhaps most important, the female dummy remains extremely large and negative with an asymptotic $t$-statistic approaching 6 . The statistic $\rho$ is significant and suggests that much of the unexplained variance in receiving piece rates is due to unobserved differences between individuals or the "random effects."

The piece-rate estimations show a similar story, with many of the coefficients retaining statistical significance in the direction already indicated. Interestingly, the positive influence of establishment size on the provision of piece rates, commonly found in the establishment studies and predicted by our theoretical model, is confirmed for the first time. However, it is offset by a negative coefficient on size for the commission equation, emphasizing again the sharp difference in determinants. Critically, the female coefficient remains very large and positive with a $t$-statistic above 7.5.

\section{Summary and Conclusions}

The evidence clearly indicates that the broad individual performance-pay variable does not reasonably substitute for the narrower measures of piece rates, commissions, and bonuses. The results for commissions and bonuses largely drive the determinants of the broader measure but differ substantially from those for piece rates. Critical among the differences is the role of gender. While women are less likely to be paid by commissions and bonuses, they are more likely to be paid piece rates. Previous attempts to use broad performance-pay variables to test theoretical predictions derived for piece rates thus appear inappropriate.

Four basic conclusions flow from disaggregating the broad variable to focus on commissions among sales workers and piece rates among craft and operative workers. First, many of the proxies of expected tenure and labor force attachment are important determinants of the likelihood of receiving performance pay. Second, these proxies appear routinely to take opposite signs as determinants of commissions and as determinants of piece rates. It appears that those with higher expected tenure and labor force attachment are more likely to be paid commissions but less likely to be paid piece rates. Third, despite the role of the proxies, the role of gender (a proxy itself) 


\section{TABLE 5}

Random-EFfect Probit Estimation, 1988-1990

\begin{tabular}{|c|c|c|}
\hline Variable & $\begin{array}{c}\text { Commission }^{a} \\
\text { (Sales Occupations) }\end{array}$ & $\begin{array}{c}\text { Piece Rate }^{a} \\
\text { (Craft and Operative Occupations) }\end{array}$ \\
\hline Female & $\begin{array}{c}-1.4734^{* * * *} \\
(0.2556)\end{array}$ & $\begin{array}{c}1.0865^{* * *} \\
(0.1433)\end{array}$ \\
\hline Age & $\begin{array}{l}0.0931^{* * *} \\
(0.0429)\end{array}$ & $\begin{array}{l}0.0419^{*} \\
(0.0235)\end{array}$ \\
\hline White & $\begin{array}{c}0.151 \\
(0.2421)\end{array}$ & $\begin{array}{l}-0.0637 \\
(0.1285)\end{array}$ \\
\hline Married & $\begin{array}{c}0.2223 \\
(0.2017)\end{array}$ & $\begin{array}{c}0.0171 \\
(0.1243)\end{array}$ \\
\hline Education & $\begin{array}{l}0.1192 * * \\
(0.0582)\end{array}$ & $\begin{array}{l}-0.0192 \\
(0.0346)\end{array}$ \\
\hline AFQT & $\begin{array}{l}0.0094^{* *} \\
(0.0048)\end{array}$ & $\begin{array}{c}0.0024 \\
(0.0028)\end{array}$ \\
\hline Supervisor & $\begin{array}{c}-0.623 * * * \\
(0.171)\end{array}$ & $\begin{array}{c}-0.4071^{* * * *} \\
(0.1181)\end{array}$ \\
\hline Size & $\begin{array}{c}-0.1168^{* *} \\
(0.0491)\end{array}$ & $\begin{array}{l}0.0546 * * \\
(0.0256)\end{array}$ \\
\hline Spells not working & $\begin{array}{l}-0.3047^{*} \\
(0.1636)\end{array}$ & $\begin{array}{r}-0.172 * * \\
(0.0853)\end{array}$ \\
\hline Union & $\begin{array}{l}-0.4647 \\
(0.3555)\end{array}$ & $\begin{array}{l}-0.0313 \\
(0.1249)\end{array}$ \\
\hline Home hours & $\begin{array}{c}3.4065^{* * * *} \\
(0.6619)\end{array}$ & $\begin{array}{l}1.6649^{* *} \\
(0.6942)\end{array}$ \\
\hline Employer training & $\begin{array}{l}0.3525^{* *} \\
(0.1778)\end{array}$ & $\begin{array}{c}-0.165 \\
(0.1136)\end{array}$ \\
\hline Dependents & $\begin{array}{l}-0.1668^{*} \\
(0.0950)\end{array}$ & $\begin{array}{l}0.0808^{*} \\
(0.0463)\end{array}$ \\
\hline Full-time & $\begin{array}{c}0.0665 \\
(0.2301)\end{array}$ & $\begin{array}{l}-0.0643 \\
(0.1835)\end{array}$ \\
\hline Young child & $\begin{array}{l}0.1998 \\
(0.2172)\end{array}$ & $\begin{array}{l}-0.0937 \\
(0.1242)\end{array}$ \\
\hline Experience & $\begin{array}{l}0.0017^{*} \\
(0.001)\end{array}$ & $\begin{array}{l}-0.0001 \\
(0.0006)\end{array}$ \\
\hline Medium tenure & $\begin{array}{c}0.1471 \\
(0.2181)\end{array}$ & $\begin{array}{l}-0.1379 \\
(0.1352)\end{array}$ \\
\hline High tenure & $\begin{array}{l}-0.5661^{*} \\
(0.3027)\end{array}$ & $\begin{array}{l}-0.1316 \\
(0.1773)\end{array}$ \\
\hline Expectations & $\begin{array}{l}-0.2672 \\
(0.2161)\end{array}$ & $\begin{array}{c}0.0052 \\
(0.1189)\end{array}$ \\
\hline Constant & $\begin{array}{c}-5.4115^{* * * *} \\
(1.3405) \\
\end{array}$ & $\begin{array}{c}-4.1615^{* * * *} \\
(0.7986)\end{array}$ \\
\hline 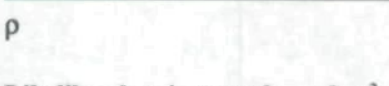 & $\begin{array}{l}0.8529 \\
(0.027)\end{array}$ & $\begin{array}{c}0.7562 \\
(0.0311)\end{array}$ \\
\hline Likelihood ratio test of $\rho=0, \chi^{2}$ & $260.64^{* * *}$ & $334.87^{* * *}$ \\
\hline $\begin{array}{l}\text { Observations } \\
\text { Groups }\end{array}$ & $\begin{array}{l}1934 \\
1276\end{array}$ & $\begin{array}{l}6454 \\
3348\end{array}$ \\
\hline $\begin{array}{l}\text { Groups } \\
\text { Wald } \chi^{2}\end{array}$ & $\begin{array}{c}1276 \\
123.64^{* * *}\end{array}$ & $\begin{array}{c}3348 \\
106.94^{* * * *}\end{array}$ \\
\hline
\end{tabular}

"The entries are coefficients and standard errors are in parentheses.

***:Significant at $1 \%$ level.

** Significant at $5 \%$ level.

*Significant at $10 \%$ level. 
remains robust. Women remain significantly more likely to be paid by piece rates and significantly less likely to receive commissions or bonuses. Fourth, these conclusions are not altered by attempts to account for selection into the relevant subsamples or to estimate error-components models adjusting for random effects.

It may be tempting to conclude from these results that gender sorting by payment schemes is necessarily efficient. While this may be so, there are reasons for caution. One would anticipate that efficient sorting should result in women on piece rates being more satisfied, but what evidence exists suggests just the opposite (Heywood and Wei 1999). Women on piece rates express less job satisfaction even after controlling for personal characteristics, job characteristics, earnings, predicted earnings, and fringe benefits. This raises the possibility that some of the sorting may better be identified as "crowding." It could be that the jobs associated with piece rates are disproportionately those associated with "women's work," such as the needle trades, and that this cultural association persists. Despite this possibility, the work presented here highlights the importance of recognizing the profound differences that gender plays in the provision of different types of individual performance pay.

\section{REFERENCES}

Alchian, Armen, and Harold Demsetz. 1972. "Production Costs, Information and Economic Organization." American Economic Review 62:777-95.

Beckmann, Petra. 1998. "Working Hours and Wishes Concerning Working Hours Among Women in Germany," Working paper no. 27, Institute for Employment Research, Federal Office for Labor, Nuremberg, Germany.

Belman, Dale, and John S. Heywood. 1988. "Incentive Schemes and Racial Wage Discrimination." Review of Black Political Economy 17(Summer):47-56.

Bender, Keith, Susan M. Donohue, and John S. Heywood. 2001. "Job Satisfaction and Gender Segregation in the U.S. and U.K.: Are Women Happier Together?" Working paper, Graduate Program in Human Resources and Labor Relations, University of Wisconsin-Milwaukee.

Blau, Francine D., Marianne A. Ferber, and Anne E. Winkler. 1998. The Economics of Women, Men, and Work, 3d ed. Upper Saddle River, NJ: Prentice-Hall.

Booth, Alison L., and Jeff Frank. 1999. "Earnings, Productivity, and Performance-Related Pay.” Journal of Labor Economics 17(Summer):447-63.

Brown, Charles. 1990. "Firms' Choice of Method of Pay." Industrial and Labor Relations Review 43(February): $165 \mathrm{~s}-82 \mathrm{~s}$.

- and James Medoff. 1989. "The Employer Size-Wage Effect," Journal of Political Economy $74: 165-82$.

Brown, Michelle, and John Heywood. 2001. "The Determinants of Incentive Schemes: Evidence from Panel Data." Working paper, Graduate Program in Human Resources and Labor Relations, University of Wisconsin-Milwaukee.

Butler, J. S., and Robert Moffit. 1980. "A Computationally Efficient Quadrature Procedure for a One Factor Multinomial Probit Model." Econometrica 50:761-4. 
Corcoran, Mary, and Greg J. Duncan. 1979. "Work History, Labor Force Attachment, and Earnings Differences Between the Races and Sexes." Journal of Human Resources 14(Winter):3-20.

Cowling, Marc. 2000. "Performance Related Pay in Belgium and The Netherlands." Applied Economics Letters 7(10):653-7.

2001. "Fixed Wages or Productivity Pay: Evidence from 15 EU Countries." Small Business Economics 16:191-204.

Drago, Robert, and John S. Heywood. 1995. "The Choice of Payment Schemes: Australian Establishment Data." Industrial Relations 34(4):507-31.

Deardorff, Alan, and Frank Stafford. 1976. "Compensation of Co-operating Factors." Economica 44:671-84.

Duncan, Greg, and Frank Stafford. 1980. "Do Union Members Receive Compensating Differentials?" American Economic Review 70:355-71.

Ewing, Bradley T. 1996. "Wages and Performance-Based Pay: Evidence from the NLSY." Economics Letters 51:241-46.

Goldin, Claudia. 1986. "Monitoring Costs and Occupational Segregation by Sex: A Historical Analysis." Journal of Labor Economics 4(January):1-27.

Heckman, James J. 1979. "Sample Selection Bias as a Specification Error." Econometrica 47:153-61.

Heywood, John S., and Uwe Jirjahn. 2002. "Gender and Payment Schemes in Germany." Industrial and Labor Relations Review 56:44-64.

- and Xiangdong Wei. 1997. "Piece-Rate Payment Schemes and the Employment of Women: The Case of Hong Kong." Journal of Comparative Economics 25(October):237-55. and 1999. "Performance Pay and Job Satisfaction." Working Paper, Graduate Program in Human Resources and Labor Relations, University of Wisconsin-Milwaukee.

, Olaf Hubler, and Uwe Jirjahn. 1998. "Variable Payment Schemes and Industrial Relations: Evidence from Germany." Kyklos 51(February):237-57.

— W. S. Siebert, and Xiangdong Wei. 1997. "Payment by Results Systems: British Evidence." British Journal of Industrial Relations 35(March):1-22.

Jacoby, Sanford. 1997. Modern Manors: Welfare Capitalism Since the New Deal. Princeton, NJ: Princeton University Press.

Kandel, Eugene, and Edward P. Lazear. 1992. "Peer Pressure and Partnerships." Journal of Political Economy 100(August):801-17.

Lazear, Edward P. 1979. "Why Is There Mandatory Retirement?" Journal of Political Economy 87(December):1261-84.

- 1981. "Agency, Earnings Profiles, Productivity and Hours Restrictions." American Economic Review 71(September):606-20.

_. 1986. "Salaries and Piece Rates." Journal of Business 59(July):405-31.

1996. "Performance Pay and Productivity." Working paper no. 5672, National Bureau of Economic Research, Cambridge, MA.

Lynch, Lisa M. 1992. "Private Sector Training and the Earnings of Young Workers." American Economic Review 82(March):299-312.

MacLeod, W., and D. Parent. 1999. "Job Characteristics and the Form of Compensation." In Research in Labor Economics, Vol. 18, edited by Solomon Polachek, pp. 177-242. Stamford, CT: JAI Press.

Parent, Daniel. 1999. "Methods of Pay and Earnings: A Longitudinal Analysis." Industrial and Labor Relations Review 53(October):71-86.

Pencavel, John. 1977. "Work Effort, On-the-Job Screening, and Alternative Methods of Remuneration." In Research in Labor Economics, Vol. 1, edited by Ronald Ehrenberg, pp. 225-8. Greenwich, CT: JAI Press.

Seltzer, Andrew. 1998. "Hiring, Pay, Promotion and Job Security in an Internal Labor Market: Evidence from the Union Bank of Australia." Working paper no. DPE 98/5, Department of Economics, Royal Holloway College, University of London.

Siebert, W. S., and John Addison. 1991. "Internal Labor Markets: Causes and Consequences." Oxford Review of Economic Policy 7:76-92. 


\section{4 / Lori A. Geddes and John S. HeYwood}

Van de Ven, W. P. M., and B. M. S. Van Pragg. 1981. "The Demand for Deductibles in Private Health Insurance." Journal of Econometrics 17:229-52.

Weitzman, Martin, and Douglas Kruse. 1990. "Profit Sharing and Productivity." In Paying for Productivity, edited by Alan Blinder, pp. 95-140. Washington: Brookings Institution.

Wood, Robert, Mary Corcoran, and Paul Courant. 1993. "Pay Differences Among the Highly Paid: The Male Female Earnings Gap in Lawyers." Journal of Labor Economics 11:417-41. 
Copyright of Industrial Relations is the property of Blackwell Publishing Limited. The copyright in an individual article may be maintained by the author in certain cases. Content may not be copied or emailed to multiple sites or posted to a listserv without the copyright holder's express written permission. However, users may print, download, or email articles for individual use. 